\title{
Reproductive biology of the biofuel plant Jatropha curcas in its center of origin
}

Manuel Rincón-Rabanales, Laura I. Vargas-López, Lourdes Adriano-Anaya, Alfredo Vázquez-Ovando, Miguel Salvador-Figueroa, Isidro Ovando-Medina

In this work, we studied the main characteristics of flowering, reproductive system and diversity of pollinators for the biofuel plant Jatropha curcas (L.) in a site of tropical southeastern Mexico, within its center of origin. The plants were monoecious with inflorescences of unisexual flowers. The male flowers produced from 3062 to 5016 pollen grains (266-647 per anther). The plants produced fruits with both geitonogamy and xenogamy, although insect pollination significantly increased the number and quality of fruits. A high diversity of flower visiting insects ( 36 species) was found, of which nine were classified as efficient pollinators. The native stingless bees Scaptotrigona mexicana (Guérin-Meneville) and Trigona (Tetragonisca) angustula (Latreille) were the most frequent visitors and their presence coincided with the hours when the stigma was receptive. It is noteworthy that the female flowers open before the male flowers, favoring xenogamy, which may explain the high genetic variability reported in J. curcas for this region of the world. 


\section{Reproductive biology of the biofuel plant Jatropha curcas in its center of origin}

2

3 M Rincón-Rabanales, LI Vargas-López, ML Adriano-Anaya, A Vázquez-Ovando, M Salvador-

4 Figueroa, I Ovando-Medina*

5

6 Universidad Autónoma de Chiapas. Instituto de Biociencias. Boulevard Príncipe Akishino sin

7 número, Col. Solidaridad 2000, Tapachula, 30798, Chiapas, Mexico. Tel. and Fax: $+52+962$

$8 \quad 6427972$

$9 *$ Corresponding author

\section{Abstract}

12 In this work, we studied the main characteristics of flowering, reproductive system and diversity 13 of pollinators for the biofuel plant Jatropha curcas (L.) in a site of tropical southeastern Mexico, 14 within its center of origin. The plants were monoecious with inflorescences of unisexual flowers. 15 The male flowers produced from 3062 to 5016 pollen grains (266-647 per anther). The plants 16 produced fruits with both geitonogamy and xenogamy, although insect pollination significantly

17 increased the number and quality of fruits. A high diversity of flower visiting insects (36 species)

18 was found, of which nine were classified as efficient pollinators. The native stingless bees

19 Scaptotrigona mexicana (Guérin-Meneville) and Trigona (Tetragonisca) angustula (Latreille)

20 were the most frequent visitors and their presence coincided with the hours when the stigma was

21 receptive. It is noteworthy that the female flowers open before the male flowers, favoring

22 xenogamy, which may explain the high genetic variability reported in J. curcas for this region of 23 the world. 
24 Keywords: pollination, geitonogamy, xenogamy, stingless bees.

25

26

27

\section{Introduction}

Jatropha curcas (L.) (Euphorbiaceae), possibly native to Mexico and Central America [1,2], is considered the most promising non-edible plant for the production of biofuels. Many countries have established programs for its commercial cultivation [3]. In the Mesoamerican region, where the greatest genetic diversity of populations of $J$. curcas has been found [2,4-6], monocultures are being established, for example in Guatemala and the Mexican states of Chiapas and Michoacan [7].

When establishing new extensive crops, a multitude of factors must be taken into account, among which stands out reproductive biology [8], i.e., knowledge about flowering, phenological behavior, sexual system, and fruit and seed production.

Studies on floral biology and pollination ecology of $J$. curcas have been conducted, mainly in regions where this species is exotic, as in India [9-16]. Following from these studies, it is known that $J$. curcas is a monoecious species that presents geitonogamy and xenogamy; however, the first process, also called self-pollination, is prevalent. This could explain the low genetic diversity in Asian germplasm. It is possible that environment is affecting the prevalence of geitonogamy or xenogamy [17].

In the center of origin and diversity of $J$. curcas no such studies have been conducted, thus the sexual system and mode of pollination are unknown. Such knowledge could help design strategies to increase crop productivity; i.e. promoting efficient pollinators in commercial plantations. The aim of this study was to characterize the pollination process in J. curcas under field conditions at a site in southeastern tropical Mexico. 


\section{Material and Methods}

2.1 Study site and biological material

50 The study was conducted within the living fences of a farm plot at Soconusco, Chiapas, Southern

51 Mexico (14.5036 N, 92.1704 W, 58 meters above sea level). In this zone the average annual

52 temperature is $31^{\circ} \mathrm{C}$, the average annual humidity is $80 \%$, and the average of rainfall is 2600

$53 \mathrm{~mm}$ (Weather Station: 769043 MMTP of the Water National Commission, Mexico). The soil

54 type was andosol with $\mathrm{pH} 5.7,2.5 \%$ of organic matter and $0.2 \%$ of total nitrogen. Plants were

55 selected based on their appearance (healthy and abundant foliage; approximately a $10 \%$ of the

56 plants of the fence had foliar damage) and location (in a sunny area), on a $600 \mathrm{~m}$ transect. The

57 living fence was 10 years old and underwent annual pruning. According to people living in the

58 surrounding communities, the studied plants are considered toxic, with occasional cases of

59 children intoxication caused by seed ingestion.

$60 \quad 2.2$ Floral phenology

61 Flowering and fruiting dynamics were studied in 10 plants every 14 days during one year. We

62 determined the average number of inflorescences per primary branch. In five inflorescences per

63 plant, randomly selected, male and female flowers were counted. To estimate the time of flower

64 anthesis and stigma receptivity, in other 10 plants, an inflorescence in the stage of flower buds

65 was marked and observed daily ( $30 \mathrm{~d}$ ) at intervals of every $10 \mathrm{~min}$ from $0700 \mathrm{~h}$ to $1200 \mathrm{~h}$. To

66 estimate the production of pollen and ovules, inflorescences were collected from other 10 plants

67 with closed flowers, and 20 female flowers (FF) and 20 male flowers (FM) were randomly

68 selected. Pollen grains were extracted from FM and mounted in glycerinated gelatin on a slide.

69 Pollen was quantified using a stereomicroscope and the average number of pollen grains was 
70 estimated per anther and per flower. In FF the number of carpels and the number of ovules per

71 carpel was counted. With these data the pollen to ovule ratio was estimated.

72 In order to comprehend the reproductive process, five pollination treatments were established: 1)

73 geitonogamy or artificial pollination with pollen from the same inflorescence (GEI), 2)

74 xenogamy (XEN) or artificial pollination with pollen from another plant, 3) apomixis (APO),

75 which was performed by removing the male flowers and placing non-toxic white glue

76 (Resistol ${ }^{\circledR}$, Mexico) on stigma, 4) excluding pollinators (ExP), and 5) open pollination (OpP).

77 For each of the treatments 20 inflorescences were employed, one per plant (in total 20 plants for

78 this experiment), which were covered, except in OpP, with tulle mesh bags of $1 \mathrm{~mm}$ mesh size.

79 Fertilization was checked 14 days after pollination and the number of mature fruits per treatment 80 was quantified at 55 days.

812.3 Insect flower visitors and pollinators

82 To determine insect pollinators and visitors, observations were made on ten inflorescences from

83 independent plants, from $0800 \mathrm{~h}$ to 1700 at intervals of $10 \mathrm{~min}$. For this, the time of arrival at the

84 flower was taken into account, the time they stayed, the resource used (nectar or pollen), and

85 movement among flowers of the same inflorescence and between inflorescences of the same or 86 another plant.

87 In addition insects visiting the flowers of $J$. curcas were collected on another living fence, with

88 similar characteristics, but distanced $500 \mathrm{~m}$ from the study site to avoid interference with the

89 previous experiments. For this part of the study, we sampled the area of influence of 100 plants.

90 The insect collection was performed with entomological nets from $0600 \mathrm{~h}$ to $1800 \mathrm{~h}$. All insects

91 captured were examined under stereoscope, dissected into head and thorax, and identified using

92 Ayala [18] and Michener [19] taxonomic keys. Moreover, the pollen adhered to the legs of the 
93 insects was identified by microscopy.

94 The visiting insects were classified as: a) efficient pollinators, b) occasional pollinators, c)

95 accidental pollinators, or d) pillagers. We used the following criteria: 1) number of individuals

96 collected during different times of the day, 2) recurrence and time of visit to the male and female

97 flowers, 3) behavior observed on the flowers, and 4) presence of $J$. curcas pollen (pure or mixed)

98 on different parts of the body.

$99 \quad 2.4$ Statistical analysis

100 To understand differences between visitor groups in the frequency and time of visit to male and

101 female flowers, the Chi-square test was applied. The number of fruits, and the quality of these in

102 the different treatments were compared by analysis of variance (ANOVA) and Tukey test $(\alpha=$

103 0.05).

104

1053 Results

1063.1 Flowering and anthesis time

107 The plants studied had three flowering peaks (80\%) in the months of April, May and September.

108 In the period from December to February the plants showed no flowering. Subsequent to that,

109 there were three periods of peak fruiting in the months of May, June and October. There were no

110 fruits in the months from December to March.

111 It was found that, under the study conditions, J. curcas produces an average of 1.25

112 inflorescences per branch, and the number of female flowers per inflorescence was 1-11, with an

113 average of 2.2. Meanwhile, the number of male flowers ranged from 35-198 flowers per

114 inflorescence (mean: 106.7). It was found that the proportion of female/male flowers was 1:60.

115 Pollen production by anther ranged from 266-647 pollen grains (mean: 475.1) and per flower 
116 was 3062-5016 pollen grains (mean: 4224.4). The proportion of pollen grains per ovule was

117 1408:1.

118 The male and female flowers begin to open at $0800 \mathrm{~h}$, presenting the maximum aperture of

119 female flowers $(64.29 \%)$ and male $(55.75 \%)$ at 0900 hours. The stigma was receptive at the time

120 of $1000-1200 \mathrm{~h}$.

1213.2 Pattern of flower opening

122 Flowers regularly opened over an average period of 15 days (Figure 1). The pattern showed that

123 the female flowers are the first to open and this process continues for eight days. Male flowers

124 started opening two days after the female flowers, and lasted up to 13 days, with the highest

125 peaks between days 8 and 10 .

1263.3 Diversity of insect visitors

127 The variety of insect visitors to the flowers of $J$. curcas came from 36 species, which were

128 grouped into four orders, 12 families and 16 genera as recognized (Table 1). Hymenoptera were

129 the most diverse (75\% of the species) and dominant ( $72.6 \%$ of the relative abundance) group,

130 followed by Diptera (diversity of $19.4 \%$; dominance of $26.3 \%$ ).

131 We found three types of pollinators: a) accidental, including the fly Thachinidae sp. 2, Vespidae

132 sp. 1, Vespidae sp. 2 and one species of Cerambicidae; b) occasional, comprising 14 species that

133 included bees, ants, and wasps; and c) efficient, composed nine species, of which most were bees

134 and two species of flies. The remaining insects were considered pillagers or nectar robbers

135 (Table 1). Some of the individuals were carrying pure pollen loads of J. curcas in different parts

136 of the body, while others carried J. curcas pollen mixed with other pollen types [Ageratum aff.

137 houstonianum (Mill.), Acacia aff. cornigera (L.) Willd., Tridax aff. procumbens (L.), Zea mays

138 (L.)]. Pollen from other species represented less than $10 \%$ of the total loads (Table 2). 
1393.4 Frequency of visit

140 The activity of insects visiting the flowers of $J$. curcas was continuous, starting from $0600 \mathrm{~h}$ until

141 shortly after $1800 \mathrm{~h}$, showing a markedly bimodal behavior (Figure 2). The main activity peaks

142 coincided with increased secretion of female flower nectar during daylight 0700-0900 h. The

143 greatest wealth of insects was recorded at $0900 \mathrm{~h}$ and $1000 \mathrm{~h}(\mathrm{~S}=8)$, registering the highest peak

144 at $1400 \mathrm{~h}(\mathrm{~S}=9)$ (Figure 2).

145 We found differences in the frequency and time of insects visiting the female flowers $(\chi 2=$

$14621.78, \mathrm{p}<0.01)$ and male $(\chi 2=39.69, \mathrm{p}<0.01)$. Insects observed in the marked panicles were $S$.

147 mexicana, T. (Trigona) fulviventris (Guérin), T. (Trigona) fuscipennis (Friese), Agapostemon

148 nasutus (Smith), Augochlora (Augochlora) quiriguensis (Cockerell), Augochlora aurifera

149 (Cockerell), Augochlora (Augochlora) smaragdina (Friese), Halictus (Seledonia) hesperus

150 (Smith), Tachinidae sp. 1, Eristalis aff. persa (Williston), Camponotus (Mayr) and Vespidae sp.

151 1. Compared with other groups, the bees visited more flowers (43.2\%) and stayed longer in

152 resource foraging (38\%). The second most important group was the Diptera with 39.3\%

153 (frequency) and 31\% (time of visit). Specifically, bees visited a larger number of female flowers

$154(55.6 \%)$ than male flowers (46.4\%). Both bees and flies spent more time to visiting female

155 flowers, while Vespidae sp. 1 had a preference for the male flowers. The Diptera foraged

156 exclusively nectar, while bees collected nectar and pollen.

157 3.5 Jatropha curcas reproductive system

158 We found differences in the production and quality of fruits and seeds from the different

159 reproductive systems of $J$. curcas $(\mathrm{p}<0.001)$. The highest percentage of fruit set was recorded in

160 free pollination treatments (OpP: $86.3 \pm 2.2)$ and in xenogamy (XEN: $84.3 \pm 6.3)$, being

161 statistically equal between them; followed by the treatments with exclusion of pollinators (ExP: 
$16218.1 \pm 7.2)$ and geitonogamy (GEI: $16.2 \pm 7.3)$. In the treatment of apomixis five fruits were

163 formed, of which four were aborted and only one reached maturity ( $n=55$ female flowers). The

164 only apomictic fruit had a high fresh weight, which contrasted with a low seed fresh weight, due

165 to its thick endocarp.

166 Regarding the number of fruits that reached maturity, the OpP and XEN treatments were

167 statistically superior to all other treatments $(p<0.001)$. The type of reproduction also influenced

168 the quality of fruits and seeds, as the longest fruits were recorded in the OpP and XEN treatments $169(p<0.001)$ and heaviest seeds occurred in OpP treatment (Table 3).

170

\section{Discussion}

172 Some aspects of the floral biology of J. curcas in the Mexican tropics, such as the proportion of 173 male and female flowers (1:60), differ from those reported in studies conducted with germplasm

174 from other geographic areas. For example, Raju \& Ezradanam [10] reported in India that an

175 inflorescence could produce 1 to 5 female flowers and 25-93 male flowers, with a ratio of male

176 flowers to female flowers of 1:29. Also, Pinto et al. [20] found 4-12 female flowers and 87-222

177 male flowers (relation: 1:20). This variable is not preserved and the differences depend on the

178 genetic material, geographic region, climate, nutrition, time, and cultural practices, among other

179 factors, which makes it a highly variable feature $[11,13,20]$. Pollen production per anther and per

180 flower was higher than that reported in other studies, such as Bhattacharya et al. [11], who found

181 that each flower produced 1617 pollen grains, with a ratio of pollen:ovule (P:O) of 539:1. In this

182 regard, Cruden [21] mentions that the P:O ratio is an indicator of the reproductive system. In the

183 case of $J$. curcas the P:O relation is very high, which could favor the xenogamy. On the other

184 hand, there could be a compensatory mechanism of pollen loss caused by the constant arrival of 
185 insect visitors to the inflorescences, i.e., reflecting a low efficiency in pollen transfer.

186 The anthesis of male flowers and female flowers under the conditions of this study occurred at

1870700 h, which coincides with the findings of Raju \& Ezradanam [10], who reported that the

188 flowers open daily between 0530-0630 h. Kaur et al. [16] reported that the male flowers open

189 between $0600 \mathrm{~h}$ and $0700 \mathrm{~h}$, while the female flowers open shortly after $(0700-0800 \mathrm{~h})$. The time

190 it takes for the stigma to be receptive (1-2 h) is similar to that reported by Bhattacharya et al.

191 [11]. The opening pattern of flowers in the morning was related to attracting insects, because the

192 availability of resources (nectar and pollen) is significantly higher in the morning.

193 The flowering stage of the plants studied occurred from March to November, which was

194 consistent with that reported by Sukarin et al. [9], who recorded two flowering peaks, one in

195 May and one in November. Instead, Joker \& Jepsen [22] observed that flowering occurs during

196 the dry season with two flowering peaks, these authors mention that the plants bloom throughout

197 the year in permanent wet conditions. While the fruiting stage occurred from April to December, 198 contrary to that reported by Toral et al. [23], who recorded that the fruits are produced in winter

199 when the plant loses its leaves.

200 The wealth of insects foraging on flowers of $J$. curcas located in the southeastern area of the

201 Mexican tropics was high (Table 2). However, of the 32 species of potential pollinators, not all

202 were efficient as pollinators of J. curcas, because not all visited the flowers of both sexes, or they

203 did not transport pollen on their body, or they did not coincide with the period of stigma

204 receptivity. According to these observations, it was determined that an efficient pollinator for $J$.

205 curcas was one that (i) visited several flowers of $J$. curcas during foraging [15], (ii) frequently

206 shifted from one flower to another [15,24], (iii) transported specific pollen abundantly on its

207 body, and (iv) was observed sliding some part of its body on the receptive stigma. 
208 The most abundant insects were Hymenoptera and Diptera, which is consistent with some 209 previous studies in other areas [25], but contrasts in the case of Diptera that have been cited as

210 efficient pollinators of flowers of $J$. curcas, but which are not always present or are less diverse

211 and abundant $[10,11]$. There is a high diversity and abundance of bees (19 species) and flies (9

212 species). Bees were generally small to medium size $(5-10 \mathrm{~mm})$ and particularly the native

213 stingless bees were the most diverse, abundant, and with morphological characteristics

214 correspondent to the floral syndromes of $J$. curcas. In general, the Diptera had body sizes 7-14

$215 \mathrm{~mm}$ and abundant pilosity on the body, but their behavior does not allow cataloging them as

216 efficient pollinators. Two exceptions were Eristalis sp. and Tachinidae sp. 1, which frequently

217 visited male flowers looking for fresh nectar and transported pure pollen stuck onto their body

218 for more than nine hours a day. They were observed simultaneously visiting female flowers for

219 nectar during the period of maximum stigma receptivity facilitating xenogamy and geitonogamy,

220 whereby they were classified as efficient pollinators. Our observations are consistent with studies

221 by Raju \& Ezradanam [10], who found that the Diptera Chrysomya megacephala (Fabricius) was

222 an efficient pollinator that promoted xenogamy and geitonogamy. Conversely, Rianti et al. [15]

223 reported only Eristalis tenax (L.) as an infrequent visitor and not an efficient pollinator for $J$.

224 curcas in West Java.

225 Native stingless bees S. mexicana, T. (T.) angustula, T. (T.) fulviventris, T. (T.) fuscipennis, $H$.

226 (S.) hesperus and A. nasutus are of small body size $(5-8 \mathrm{~mm})$, with special structures for

227 transporting pollen and a great quantity of specialized hairs [26]. It is possible that these

228 characteristics enable them to efficiently perform the flow of pollen to the stigma of $J$. curcas, as

229 has been observed in other species of bees $[10,11,15,27]$.

230 In the present study, A. mellifera (L.) was infrequent in relation to other efficient pollinators ( $\mathrm{n}=$ 
231 3) and recorded only between 0800 and $0900 \mathrm{~h}$. Additionally, two individuals transported $J$.

232 curcas pollen in great abundance, in the head, chest and legs, while one of them transported

233 pollen from different plant species. This result is contrary to most previous studies where $A$.

234 mellifera has been registered as the most efficient pollinator in J. curcas [10-12,14-16,28]. We

235 classify this species as occasional pollinator for $J$. curcas at this site in the Mexican tropics, and

236 it can perform both geitonogamy and xenogamy.

237 The polylectic behavior of stingless bees has been reported in previous work, and this is due to

238 the different sources of pollen that they forage for food. However, it has been reported that these

239 bees can temporarily present an oligolectic strategy, taking advantage of a single source of food,

240 as it occurs with Cocos nucifera (L.), Manguifera indica (L.), Carica papaya (L.), Citrus limon

241 (L.) and Capsicum annuun (L.) [29]. Our data show that the efficient pollinating bees have

242 oligolectic or monolectic behavior, at least during the season studied. Among those bees are

243 included S. mexicana and T. (T.) angustula, which live in nests organized within tree trunks,

244 have reduced foraging dispersion, and intensively use the floral resources available, for which

245 they have a potential as inducers of pollination of extensive crops of $J$. curcas.

246 The increased production of fruits $(86.3 \%)$ was recorded in open-pollinated plants and in

247 xenogamy treatment $(84.3 \%)$, consistent with the findings of other authors $[10,12,13]$. However,

248 a low fruit set $(50-53 \%)$ is also reported in open-pollinated flowers [12]. Regarding the

249 phenomenon of apomixis, we found a very low rate (2.5\%), similar to that found by Santos et al.

250 [30] in a semiarid region in Brazil (5\%). In contrast, Bhattacharya et al. [12] and Kaur et al. [16]

251 reported that apomixis might be responsible for the formation of more than $30 \%$ of the fruits.

252 Chang-Wei et al. [13] reported a moderate effect of apomixis (12\%). 
253 The genetic diversity of $J$. curcas in this Mesoamerican area and particularly in this region of

254 Mexico is high [1,4-6], and this may be largely due to the efficient pollination service by native

255 stingless bees, to the strong trend for protogyny leading to pollination by xenogamy, and to the

256 low prevalence of geitonogamy. Based in our results, strategies to improve the productivity of $J$.

257 curcas in commercial plantations could be designed, for example increasing artificially the 258 population of efficient pollinators as the stingless native bee S. mexicana.

\section{Acknowledgements}

261 We thank the Hermanos Ávalos Ranch, in Tapachula, Chiapas, for allowing us to conduct the

262 study in living fences on their property. We are thankful with El Colegio de la Frontera Sur, for 263 the support to identify Halictideae and stingless bees.

265 References

266 [1] Ovando-Medina I, Adriano-Anaya L, Vázquez-Ovando A, Ruiz-González S, Rincón267 Rabanales M, Salvador-Figueroa M. Genetic diversity of Jatropha curcas in Southern Mexico. 268 In: Bahadur B, Sujatha M, Carels N, editors. Jatropha, challenges for a new energy crop, Vol 2, 269 New York: Springer; 2013, p. 219-50.

270 [2] Salvador-Figueroa M, Magaña-Ramos J, Vázquez-Ovando JA, Adriano-Anaya ML, Ovando271 Medina I. Genetic diversity and structure of Jatropha curcas L. in its centre of origin. Plant 272 Genet Res 2014; doi:10.1017/S1479262114000550

273 [3] Renner A, Zelt T. Global market study on Jatropha. London: Gexsi LLP; 2008, p. 1-30 
274 [4] Basha SD, Francis G, Makkar HPS, Becker K, Sujatha MA. Comparative study of 275 biochemical traits and molecular markers for assessment of genetic relationships between 276 Jatropha curcas L. germplasm from different countries. Plant Sci 2009;176:812-23.

277 [5] Ambrosi DG, Galla G, Purelli M, Barbi T, Fabbri A, Lucretti S, Sharbel TF, Barcaccia G. 278 DNA markers and FCSS analyses shed light on the genetic diversity and reproductive strategy of 279 Jatropha curcas L. Divers 2010; 5:810-36.

280 [6] Ovando-Medina I, Espinosa-García FJ, Núñez-Farfán JS, Salvador-Figueroa M. State of the 281 art of genetic diversity research in Jatropha curcas. Sci Res Essays 2011;6:1709-19.

282 [7] Ovando I, Adriano L, Salvador M, Ruiz S, Vázquez A. Piñón (Jatropha curcas): bioenergía 283 para el desarrollo de Chiapas. Biotecnol Agrop Biodivers Chiapas 2009;2:1-25.

284 [8] Silva C, Torezan H. Reproductive biology of tropical plants. In: Claro K, Oliveira P, Rico285 Gray V, editors. Tropical biology and conservation management. Oxford; UNESCO 2008.

286 [9] Sukarin W, Yamada Y, Sakaguchi S. Characteristics of physic nut, Jatropha curcas L. as a 287 new biomass crop in the tropics. Japan Agric Res Quart 1987;20:302-3.

288 [10] Raju SAJ, Ezradanam V. Pollination ecology and fruiting behaviour in a monoecious 289 species, Jatropha curcas L. (Euphorbiaceae). Curr Sci India 2002;83:1395-98.

290 [11] Bhattacharya A, Datta K, Kumar SD. Floral biology, floral resources constraints and 291 pollination limitation in Jatropha curcas L. Pak J Biol Sci 2005;8:456-60.

292 [12] Dhillon RS, Hooda MS, Handa AK, Ahlawat KS, Kumar Y, Subha SH, Singh N. Clonal 293 propagation and reproductive biology of Jatropha curcas L. Indian J Agroforest 2006;8:18-27.

294 [13] Chang-Wei L, Kun L, You C, Yong-Yu S. Floral display and breeding system of Jatropha 295 curcas L. Forest Stud China 2007a;9:114-19. 
296 [14] Quin Y, Ping PD, Biao DZ, Liang W, Xiang SQ. Study on pollination biology of Jatropha 297 curcas (Euphorbiaceae). J South China Agricult Univ 2007;28:62-6.

298 [15] Rianti P, Suryobroto B, Atmowidi T. Diversity and effectiveness of insect pollinators of 299 Jatropha curcas L. (Euphorbiaceae). J Biosci 2010;17:38-42.

300 [16] Kaur K, Dhillon GPS, Gill R. Floral biology and breeding system of Jatropha curcas in 301 north-western India. J Trop Forest Sci 2011;23:4-9

302 [17] Heller J. Physic nut, Jatropha curcas L. Promoting the conservation and use of 303 underutilized and neglected crops. Rome: IPGRI; 1996, p. 10-11

304 [18]Ayala R. Revisión de las abejas sin aguijón de México (Hymenoptera: Apidae: Meliponini).

305 Folia Entomol Mex 1999;106:1-123

306 [19] Michener CD. The bees of the world. in: Johns Hopkins Univ Press, editors. Baltimore; 307 2007. p. $122-832$

308 [20] Pinto AC, Pimenta S, Oliveira B, Batista D, Oliveira H. Biologia floral e polinização 309 artificial de pinhão-manso no norte de Minas Gerais. Pesq. Agropec. Bras.2009;44:1073-77.

310 [21] Cruden RW. Pollen-ovule ratios: conservative indicator of breeding systems in flowering 311 plants. Evol 1997;31:32-46.

312 [22] Joker D, Jepsen J. Jatropha curcas L. Seed Leaflet 2003;83:1-2

313 [23] Toral OC, Iglesias JM, Montes OS, Sotolongo JA, García S, Torsti M. Jatropha curcas L., 314 una especie arbórea con potencial energético en Cuba. Pastos Forrajes 2008;3:191-207.

315 [24] Free JB, Williams IH. The pollination of crops by bees. Apimondia Pub House: Bucharest; 316 1977, p. 1-14 
317 [25] Luo CW, Huang ZY, Chen XM, Li K, Chen Y, Sun Y. Contribution of diurnal and

318 nocturnal insects to the pollination of Jatropha curcas (Euphorbiaceae) in southwestern China. J

319 Econ Entomol 2011;1:149-154

320 [26] Roubik DW Ecology and natural history of tropical bees. New York: Cambridge University

321 Press; 1989, p. 43-70

322 [27] Atmowidi T, Rianti P, Sutrisna A. Pollination effectiveness of Apis cerana Fabricus and 323 Apis mellifera Linnaeus in Jatropha curcas L. (Euphorbiaceae). Biotropica 2008;15:129-34

324 [28] Chang-Wei L, Kun L, You C, Yong-Yu S, Wen-Yun Y. Pollen viability, stigma receptivity 325 and reproductive features of $J$. curcas L. (Euphorbiaceae). J. Northwest Plant 2007b;27:19943262001.

327 [29] Martínez E, Cuadriello J, Ramírez E, Medina M, Sosa M, Melchor J. Foraging of 328 Nannotrigona testaceicornis, Trigona (Tetragonisca) angustula, Scaptotrigona mexicana and 329 Plebeia sp. in the Tacaná region, Chiapas, Mexico. Grana 1994;33(4-5):205-17. 
341

342

Tables

343

344 Table 1. Potential pollinators of Jatropha curcas in the region of Soconusco, Sourthern Mexico

345

346

\begin{tabular}{|c|c|c|c|c|c|c|}
\hline Order & Family & Genus & Species & $\begin{array}{l}\text { Type of } \\
\text { forage }\end{array}$ & $\begin{array}{l}\text { Type of } \\
\text { visitor }\end{array}$ & $\begin{array}{l}\text { Relative } \\
\text { abundance } \\
(\%)\end{array}$ \\
\hline \multirow[t]{27}{*}{ Hymenoptera } & Apidae & Apis & mellifera Linneo & 1,2 & OP & 1.1 \\
\hline & & Trigona & fulviventris Guérin & 1,2 & EP & 7.3 \\
\hline & & Trigona & fuscipennis Friese & 1,2 & EP & 1.1 \\
\hline & & Nannotrigona & perilampoides Cresson & 1,2 & OP & 0.4 \\
\hline & & Scaptotrigona & mexicana Guérin-Meneville & 1,2 & EP & 30.5 \\
\hline & & Tetragonisca & angustula Lepeletier & 1,2 & EP & 7.3 \\
\hline & & Oxitrigona & mediorufa Cockerell & 1 & $\mathrm{OP}$ & 0.4 \\
\hline & & Melipona & beecheii Bennett & 1,2 & OP & 0.4 \\
\hline & & Melipona & solani Cockerell & 1,2 & OP & 0.4 \\
\hline & & Ceratina & capitosa Smith & 1,2 & OP & 0.4 \\
\hline & & Triepeolus & sp. Robertson & 1 & PI & 0.4 \\
\hline & Halictidae & Agapostemon & nasutum Smith & 1,2 & EP & 7.3 \\
\hline & & Augochlora (Augochlora) & quiriguensis Cockerell & 1,2 & OP & 0.7 \\
\hline & & Augochlora (Oxystoglossella) & aurifera Cockerell & 1,2 & EP & 0.7 \\
\hline & & Augochlora (Augochlora) & smaragdina Friese & 1,2 & OP & 0.4 \\
\hline & & Halictus (Halictus) & ligatus Say & 1,2 & OP & 0.4 \\
\hline & & Halictus (Seladonia) & hesperus Smith & 1,2 & EP & 9.1 \\
\hline & & Lasioglossum (Dialictus) & sp. 1 Robertson & 1,2 & OP & 0.4 \\
\hline & & Lasioglosum (Dialictus) & sp. 2 Robertson & 1,2 & $\mathrm{OP}$ & 0.4 \\
\hline & Formicidae & Camponotus & sp. 1 Mayr & 1 & OP, PI & 0.4 \\
\hline & & Crematogaster & sp. 1 Lund & 1 & OP, PI & 0.4 \\
\hline & & Crematogaster & sp. 2 Lund & 1 & OP, PI & 0.4 \\
\hline & Sphecidae & - & sp. 1 & 1 & PI & 0.4 \\
\hline & Sphecidae & - & sp. 2 & 1 & PI & 0.4 \\
\hline & Sphecidae & - & sp. 3 & 1 & PI & 0.4 \\
\hline & Vespidae & - & sp. 1 & 1 & AP, PI & 0.4 \\
\hline & Vespidae & - & sp. 2 & 1 & $\mathrm{AP}, \mathrm{PI}$ & 0.7 \\
\hline \multirow[t]{7}{*}{ Diptera } & - & - & sp. 1 & 1 & PI & 0.4 \\
\hline & Syrphidae & Eristalis & sp. 1 & 1 & EP & 7.3 \\
\hline & Tachinidae & - & sp. 1 & 1 & EP & 17.0 \\
\hline & Tachinidae & - & sp. 2 & 1 & AP, PI & 0.4 \\
\hline & Syrphidae & - & sp. 1 & 1 & PI & 0.4 \\
\hline & Bombyliidae & - & sp. 1 & 1 & PI & 0.4 \\
\hline & Tephritidae & - & sp. 1 & 1 & PI & 0.4 \\
\hline Coleoptera & Cerambycidae & - & sp. 1 & 1 & AP, PI & 0.7 \\
\hline Hemiptera & Fulgoridae & - & sp. 1 & 1 & PI & 0.4 \\
\hline
\end{tabular}

347 AP: accidental pollinator, EP: efficient pollinator, PI: pillager, OP: ocassional pollinator. 1: nectar; 2: pollen 
353

354

355

356

357

358

359

360

361

362

363

364

\begin{tabular}{lcccc}
\multicolumn{1}{c}{ Individuals } & Type of pollen loads (Number and percentage) \\
\multicolumn{1}{c}{ Species } & $\begin{array}{c}\text { Mllected } \\
\text { (n) }\end{array}$ & Pure loads & Mixed loads & Without loads \\
\hline Scaptotrigona mexicana & 84 & $55(65.5 \%)$ & $17(20.2 \%)$ & $12(14.3 \%)$ \\
Tetragonisca angustula & 19 & $14(73.7 \%)$ & $1(5.3 \%)$ & $4(21.0 \%)$ \\
Trigona fulviventris & 19 & $14(73.7 \%)$ & $2(10.5 \%)$ & $3(15.7 \%)$ \\
Trigona fuscipennis & 3 & $3(100 \%)$ & - & - \\
Halictus hesperus & 25 & $15(60 \%)$ & $3(12 \%)$ & $7(28 \%)$ \\
Agapostemon nasutum & 19 & $7(36.9 \%)$ & $2(10.5 \%)$ & $10(52.6 \%)$ \\
Tachinidae sp. 1 & 49 & $31(63.3 \%)$ & $1(2.0 \%)$ & $17(34.7 \%)$ \\
Eristalis sp. & 19 & $14(73.7 \%)$ & $2(5.3 \%)$ & $4(21.0 \%)$ \\
Apis mellifera & 3 & $1(33.3 \%)$ & $1(33.3) \%$ & $1(33.3 \%)$ \\
\hline
\end{tabular}

Table 2. Efficient pollinators of Jatropha curcas in the region of Soconusco, Southern Mexico
365

366

367

368

369

370

371

372

373

374

375

376 
383 Table 3. Comparison of characteristics of fruits and seeds obtained from different pollination treatments in Jatropha curcas in the Soconusco region, Chiapas, Mexico

\begin{tabular}{|c|c|c|c|c|c|c|c|}
\hline & OpP & XEN & GEI & $\mathbf{E x P}$ & APO* & $\mathbf{F} * *$ & $p$ \\
\hline $\begin{array}{l}\text { Fruits per } \\
\text { inflorescence (n) }\end{array}$ & $4.88^{a}$ & $4.20^{\mathrm{a}}$ & $0.88^{b}$ & $1.00^{\mathrm{b}}$ & $0.10^{\mathrm{c}}$ & 21.02 & 0.001 \\
\hline Fruit diameter $(\mathrm{cm})$ & $2.94^{\mathrm{a}}$ & $3.04^{\mathrm{a}}$ & $2.82^{\mathrm{ab}}$ & $2.64^{\mathrm{b}}$ & 2.9 & 2.98 & 0.035 \\
\hline Fruit length (cm) & $3.29^{\mathrm{a}}$ & $3.26^{\mathrm{ab}}$ & $2.98^{\mathrm{bc}}$ & $2.85^{\mathrm{c}}$ & 3.1 & 4.73 & 0.004 \\
\hline Fruit fresh weight $(\mathrm{g})$ & $12.90^{\mathrm{a}}$ & $13.10^{\mathrm{a}}$ & $12.42^{\mathrm{a}}$ & $10.07^{\mathrm{b}}$ & 13.86 & 4.48 & 0.005 \\
\hline Seeds (n) & $2.68^{\mathrm{a}}$ & $2.77^{\mathrm{a}}$ & $2.71^{\mathrm{a}}$ & $2.16^{\mathrm{b}}$ & 3.0 & 2.80 & 0.004 \\
\hline Seed fresh weight $(\mathrm{g})$ & $1.65^{\mathrm{a}}$ & $1.21^{\mathrm{b}}$ & $1.30^{\mathrm{b}}$ & $0.97^{\mathrm{c}}$ & 1.21 & 20.95 & 0.001 \\
\hline
\end{tabular}

386 OpP: open pollination, XEN: xenogamy, GEI: geitonogamy, ExP: excluding pollinators, APO: 387 apomixis.

388 *Due to the reduced number of fruits, the apomixis treatment was not included in most of the 389 ANOVA tests.

$390 * *$ One way ANOVA and Tukey tests were performed. Different superscripts letters in a row 391 denote statistical differences.

392

393

394

395

396

397

398

399

400 
409 Figure 1. Opening dynamic of female and male flowers in Jatropha curcas in the Soconusco 410 region, Chiapas, Mexico.

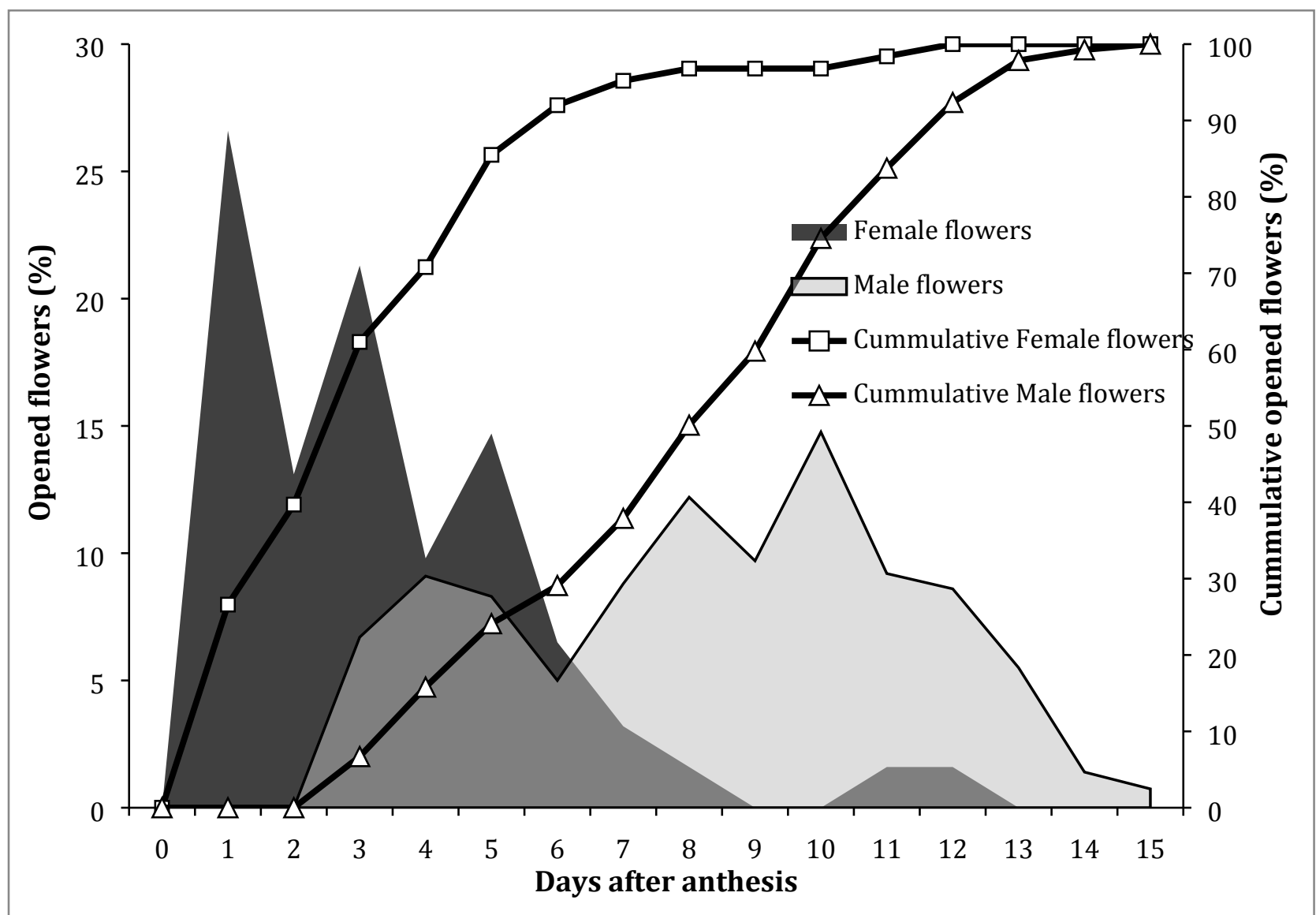


413

414

415

416

417

418

419

420

421 Figure 2. Daily dynamics of insects visiting Jatropha curcas flowers in the Soconusco 422 region, Southern Mexico.

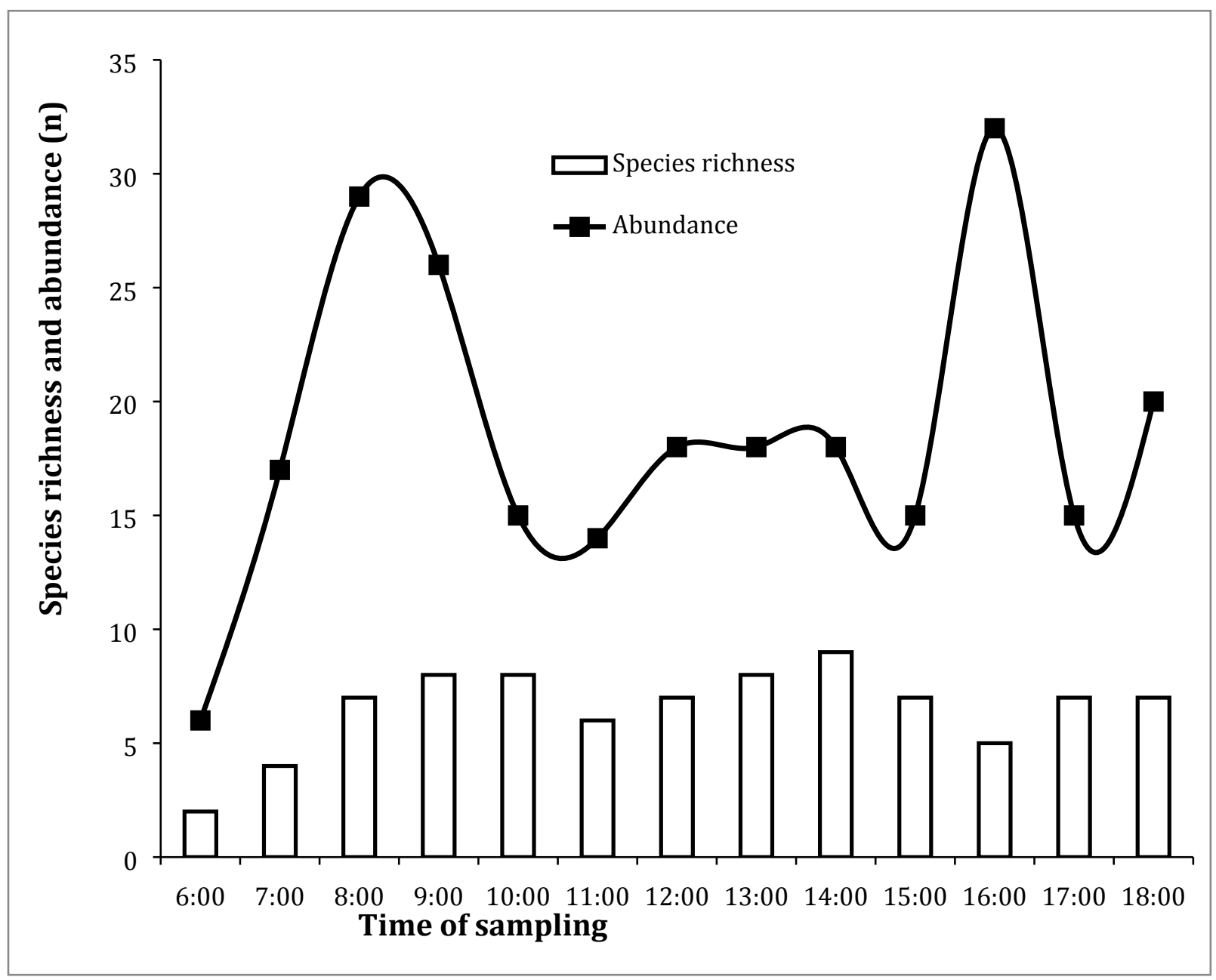


424

425

426

427

428

429

430

431

432

433

434 